\title{
The Continuity and Change of Indonesia's Islamic Higher Educational Institutions in the amid of Educational Policy Change
}

\author{
Muhammad M. Said ${ }^{1}$, Nuryani Muhammad ${ }^{2} \&$ Kaviyarasu Elangkovan ${ }^{3}$ \\ ${ }^{1}$ State College for Islamic studies Palangka Raya, Indonesia \\ ${ }^{2}$ Department of Education Muhammadiyah University of Palangka Raya, Indonesia \\ ${ }^{3}$ School of Economics and Finance, Queen Mary University of London, UK \\ Correspondence: Muhammad M. Said, State College for Islamic studies Palangka Raya, Indonesia. E-mail: \\ abiulil@yahoo.com
}

Received: October 20, 2013 Accepted: December 30, 2013 Online Published: February 26, 2014

doi:10.5539/ass.v10n6p71 URL: http://dx.doi.org/10.5539/ass.v10n6p71

\begin{abstract}
Education means either human or social capital investment to build up an intellectual community possessing wider knowledge. Some define education as a process of transferring knowledge from one generation to another. By investing in education, we tend to create a dynamic society which in return would contribute significantly to the development of nation. The main objective of this study is to explore information related to the policy in developing Islamic higher educational institutions and the strategic roles played by the respective alumni in the process of developing the community and nation. This study utilizes the valuable documents relating to the development of Islamic educational institutions as the main data sources. The data were taken from the websites of some Islamic institutions, articles written by the Muslim figure in Indonesia and from the webpage of the Director of Higher Islamic educational institution, Ministry of Religious Affairs. Primary research method was also used by interviewing the leaders of Islamic higher educational institutions to gain a broad sense of the policy changing and policy re-orientation. Data from the interviews were manually analyzed and classified into relevant ideas, themes, categories and patterns based on qualitative approaches.
\end{abstract}

Keywords: Islamic education, decentralization, accountability, and community development

\section{Introduction}

The wind of globalization that currently blows in various parts of the world profoundly and radically brings an impact in all aspect of life. Globalization manifests itself through the intensification of increased mobility of individuals, capital and information on a global scale, that is, a multicultural society is being constructed under our eyes on a global scale (Zuzeviciute, 2008). In educational world, globalization which is highly characterized by rapid growth of science and technology had demanded the educational institution to retrospect its vision and mission and develop its system not only to pour knowledge into the head of society's member from unknown to be known or their curiosity but more than that, educational institution is also demanded to have high knowledge, skills and professionals in order being able to maximally participate in the community and nation development. (Daun \& Walford, 2004).

The escalating demand on the educational institution's outcome causes the educational institution to be professionally managed in the belief that the citizens of society whom are educated from it will adapt in accordance of the market demand. In this context, academic institutions including varsities had been literally forced to change their managerial paradigm. These educational institutions should and could work according to public interest. Thus, in today's globalization era, the higher education had undergone tremendous transformation into powerful consumer-oriented and corporate networks, whose public interest values are seriously challenged (Lynch, 2010).

The change of orientation and paradigm have demanded all types and levels of educational institutions, including Islamic educational institution which has special characteristic that is bond by traditional values of Islam to change its vision and orientation. It is demanded to be responsible to the future of the society's member in order being acceptable in the market.

Responding to the policy change at international level as a source for national policy change, the decision 
makers of Islamic education in Indonesia took some changes (Jakobi, 2009). The Ministry of Religion Affairs, Mukti Ali (1972-1977) jointly signed memorandum of understanding with the Minister of Education and culture and the Minister of Home Affairs on increasing the quality of Islamic education. The policy inspired by the rising demand to place the student's position or its outcome to have high level and quality and in wide notion of citizenship (Fadjar, 2006).

The policy education took by the minister of Religion Affairs of Indonesian Republic explicitly derived by the notion and mandate of regulation and law in Indonesia (UUD, 1945) to achieve the objective of national education in general and the proper intellectual life for the youth of the nation in particular, to give equal opportunity on every Indonesian citizen to have a better job and a better life, and to provide an equal opportunity to have better education for every Indonesian citizen. It is necessary to take such a concrete step to increase the quality of madrasah education so that its outcome is able to continue their education up to the higher level (Fadjar, 2006).

The policy taken by the Ministry of Religion is understandable as the notion in placing education as a priority. By changing the policy on education as a priority, each government successfully gained the confidence of its citizen, even when certain fundamental rights such as political rights and civil liberties (Gastil, 1986). Education plays a crucial contribution in investing human capital development in the form of knowledge and skill that enables them to improve their income (Ahmed, 1992). It is seen as a key to successful development of many countries from the West to the East. (Pramanik, 1992, p. 61).

Islamic educational with its various level of institutions which begins from basic primary schools up to academy and university obtain critics from various parties across the nation. Malik Fadjar (the former Ministry of Religion and Ministry of Education and culture in Indonesia) asserted that most of that institutions are unable to be placed at the proper place as its quality insurance, its coveted role and task both for stakeholders from middle and top level and for internal needs do not meet the criteria as the future alternative for national education. It, as Samuel Bowl (1972) points out, has not assisted fostering the mobility between present generations to the next generation.

The ability of Islamic educational institution to shape the bright future as its primary outcome is still in doubt since it demands the management of the institution to be rational and consumer-based orientation. The current mainstream of education is the demand to prepare and foster its alumni to play the pivotal role and task in handling the community and nation development. It is not solely as a tool to build political influence or a missionary in the strict sense which can harm many people but should be based on a clear orientation that can help the community to have their bright future (Fadjar, 2006).

Less attraction of community towards Islamic educational institutions is not because the shifting of religious values or the religious ties which are fading, but most of the features of Islamic educational institution are less promising and less responsive to the current and future demands.

In the West countries, there is a high tendency to establish Islamic or Muslim school. A major reason for that is the failure of state schools to provide adequate spiritual and moral education. It also aimed at providing a balanced curriculum that offers a broad education and prepares them to compete for jobs in the broader multicultural society. (Mogra, 2007, p. 387; Merrya \& Drieshen, 2005), and help them become humanized or self-actualized and develop their real self and full potential (Knight, 1972).

Apart from the above critics, current system of Islamic education develops widely particularly in Indonesia. It is not only indicated by increasing its quantity and status change from the lower to middle level and even from lower level to highest level, such Sekolah Tinggi Agama Islam Negeri directly becomes Universitas Islam Negeri, passing over one step from Institute Agama Islam Negeri (IAIN). Its growth is fostered by the initiative of Ministry of Religion Affairs to expand and to change their status from Sekolah Tinggi Agama Islam to Institute Agama Islam Negeri and Institute Agama Islam to Universitas Islam Negeri (www.diktis.go.id, 2013).

This article aims to explore the condition of Islamic educational institution in Indonesia. It focuses on the higher educational institutions such as State Islamic University (Universitas Islam Negeri), State Institute for Islamic Studies (Institut Agama Islami Negeri), State College for Islamic Studies (STAIN) and Private Islamic higher educational institution (Perguruan Tinggi Agama Islam Swasta). Exploring the change of its orientation and paradigm which are needed to keep its survival in amid radical change will be the second part of this paper. The third part explores its policy change in developing its system in fostering its alumni to educated people who have comparative advantage, competitive advantage and collaborative advantage. 


\section{Theoretical Framework}

\subsection{Defining Islamic Education and Its Aims}

Traditionally, Islamic education had been provided by an Islamic system. In the late modern age, schooling which incorporates Western model was introduced. Its subject matter and educational method bore no relation whatsoever to Islam, but were related primarily to technological and economic developments for which the West had set the example. The 1977 conference on Muslim education aimed at formulating an Islamic concept of education which would surmount the duality of Islam (as present in Qur'an schools, etc.) on the one hand and Western secular science and education on the other. All knowledge must be consistent with Islam: acquired knowledge should not contradict with the revealed knowledge of the Qur'an. (Meijer, 2000).

The Arabic expression al-tarbiya al-diniyya is mostly used as a reference to religious instruction (be it Islamic or Christian) in school. The notion of 'Islamic education' (al-tarbiya al-islamiyya) carries some additional connotations. It can either refer to a specific subject in school, i.e. religious education for Muslims, or to a vision of an entire educational system imbued with Islamic values (Leirvic, 2004).

According to Syed Ali Ashraf Islamic education is an 'education in all branches of knowledge taught from the Islamic point of view'. Accordingly, it should be 'governed by the deeply felt ethical values of Islam' (Roald, 1994, p. 66).

The purpose of education is to guide the student toward these goals. People do not achieve their potential automatically, as they are forgetful by nature and open to the influence of injustice and ignorance. It is through education they could develop the wisdom and faith that will help them to love doing well and never lose sight of their relationship with God.

The fundamental aims of Islamic education is to provide student a positive guidance which help them to grow into highly moral-embedded adults who will lead happy and fruitful lives in the world and aspire others to achieve reward in the future. To know what precisely is meant by good adults require an understanding of the Islamic concept of human being (Halstead, 2004).

Islamic education stresses the importance of moral aspect. Thus Islamic education is also known as moral education that requires the cultivation of the entire divine potential in persons's nature. (Alavi, 2007). At the early stage of its development, the rationale and purposes of Islam is to keep Islamic identity, autonomy, anti-colonial struggle, and post-colonial reforms (Parka \& Niyozov, 2008; Rabasa, 2006).

Sikand (2006) state that the main purpose of Islamic education (madrasah and al jami'at/institute) is to spread the knowledge of Islam by producing Islamic religious leaders who can teach Islamic subjects such as the Qur'an, Islamic law and jurisprudence, metaphysically oriented logic and the Prophet's traditions (Boyle, 2006; Daun \& Walford, 2004; Husain, 2004). It also aimed at providing a balanced curriculum that offers a broad education and prepares students to compete for jobs in the broader multicultural society. (Mogra, 2007, pp. 387-398; Merrya \& Drieshen, 2005).

Another important goal of Islamic education is Islamisation of knowledge that comes from secular academic disciplines. Islamisation as an endeavor is as old as Islam itself. Initially, it aimed at reforming the traditions, practices, ideas, and social life of the people in the Arabian Peninsula in the territories conquered and converted. (Milligan, 2004).

\subsection{Islamic Education in the Educational Policy Change}

The affirmation of policy study is regarded as political study. Moreover, its analysis contextually refers to general intellectual activity including educational development. In the context of education, its main objective is to analyze educational policy formulation whether or not it accommodates public interest which is based by absorbing public idea, thought, and aspiration. (Dunn, 2003) in order it can be consumer-based orientation, and the relevance of its output (alumni) to the demand of work realm and community development aspect. In other words, the current policy environment regarding affirmative action mandates in higher education is to measure the impact and direct the policy toward the goals of higher education. (Johnson \& Lollar, 2002).

The key concepts in the change of educational policy are decentralization, accountability, marketization, managerialism, and professionalization. These have become key concepts in the reform discourse of policy -maker in many countries around the world. They are small and normative but solid set of policy models that are ideal representation of the ends of schooling and of the means of attaining those ends. (Zanten, 2002).

MCLean and Louglo (1985) assert that decentralization offers perhaps the mildest version of contrived change. This concept applies more to decisions to strengthen regional and local authorities in countries with tradition of 
centralized education than to countries with a long tradition of decentralization where the redistribution of responsibilities between school and local authorities has mostly justified in terms of effectiveness. The aim of decentralization, as pointed out by Broadfoot cited by Zanten (2002) is to impose new modes of education management, based on a remote steering of the system that increases State legitimacy while considerably reinforcing local agent's vulnerability to internal and external criticism.

The second concept of educational policy change is accountability. The concept has been promoted evaluation with little references to clients except at a very abstract level. There is move toward external surveillance and regulation of educational professionals that tends to alter their roles and their relationship with each other and with parents (Broadfoot, 1996; Zanten, 2002).

Contrasting to the accountability concept, marketization or managerialism discourses of professionalization that circulate internationally seem to cross ideological to empowerment in progressive one. It is perhaps possible to see in this contradiction a global process of deprofessionalization and reprofessionalization (Sedon, 2000; Zanten, 2002). Positive discourse on the professionalism of teacher can be seen either sincere or hypocritical attempt to rehabilitate teacher's work in face of reform that have tended to emphasize distrust and criticism from parents, head teacher and local and national educational authorities. The discourse on teacher's professionalization is in fact way of introducing managerial modes of control in subtle ways. This discourse focused on co-operation which, when they come from the administration, are perceived by teachers as forms of contrived collegiality (Hargreaves, 1992; Zanten, 2002).

The Department of National Education, the Republic of Indonesia used some discourse to indicate the policy change in educational sector such as autonomy, accountability, and quality. Firstly, autonomy or wider autonomy refers to managerial issue and to the term of curriculum selection in the attempt of adjusting educational institution to market requirement. The function of education is to improve the quality of human resource through mastering science and technology, social and humanity studies and such entire field through research and development. (Fadjar, 2006). Those functions are extended to the development of spiritual values in Islamic education system. Thereby, it creates human resource that enable integrating the science and technology in the framework of religious or spiritual values (al Faruqi, 1986).

Secondly is greater accountability. The discourse refers to use financial sources more responsibly and efficiently in line with the development of education content and programs which is relevant to the need of market and community development. Accountability is widely addressed either to the government as education builder or to the society and other stakeholders using its outcome (Fadjar, 2006).

Thirdly is greater quality assurance. This aspect is done through internal and external evaluation. It is conducted continuously and sustainably with the main objective to improve and to determine a more flexible and dynamic standard, thereby enabling the educational institution to make change and adjustment to work realm demand and requirement (Azra, 2000).

The implication of educational policy change in Indonesia to the Islamic educational system is change in the status of higher Islamic educational institution. It is mandated by the Law No. 2/1989 which implies the authority and autonomy of management to expand the institution in order it is able to play significant role in transferring values and knowledge to meet pragmatic aspect and spiritual as well.

Clark Kerr confirms that the function of education is not only to put link and match, to address the short term challenge and requirement but also to look for answer to the fundamental meaning of human life. It gives the opportunity to the member of society to enable them learning to know the essence, and the origin of themselves and the objective of their life, learning to do particularly in externalizing the values they absorbed from the Islamic educational institution through their real attitude and action, and learning to live together which is indicating their capability of living adjacently with heterogeneous and plural society, setting empathy and social responsibility to the front (Azizy, 2004, p. 12), setting their alumni with the pillars of faith and morality, stand on their own feet (mandiri) or self-sufficiency (kemandirian) and to (re)invente traditional value of Islamic educational institution. (Lukens-Bull, 2001; Rosenblith, 2004).

\section{Research Method}

This study utilizes the valuable documents relating to the development of Islamic educational institutions as the main data sources. The data taken from the sites of some Islamic institutions, articles written by the Indonesian Muslim figures and from the web of the Director of Higher Islamic educational institution, the Ministry of Religion Affairs. In-depth interviews with the leaders of Islamic higher educational institutions also was done in order to gain a broad sense of their policy change in leading the institutions. The other data resource is personal 
letter that contain a structure question addressed to the leader of the institutions through email. The collected data is analyzed by using the pattern suggested by Miles and Hubermas (1992) that are data display, data reduction, and drawing conclusion.

\section{Research Finding}

\subsection{Historical Sketch of Islamic Higher Education in Indonesia}

Institutionally, Islam higher education has spread throughout the country of Indonesia in the form of low level which called Sekolah Tinggi Agama Islam Negeri (STAIN)/State College for Islamic Studies, middle level, Institute Agama Islam Negeri/State Institute for Islamic Studies and the top level is Universitas Islam Negeri/Islamic State University. In its early history, Islamic educational institution was established with the issuance of Presidential Decree No. 11/1960 on the establishment of ADIA Yogyakarta which latter becomes State Institute for Islamic Studies (IAIN) or Al-Jami'ah al-Islamiyyah al-Hukumiyah centered in and inaugurated by the Minister of Religion Affairs, KH. Wahib Wahab on 24 August 1960. By July 1, 1965, the name of IAIN Yogyakarta changed to IAIN Sunan Kalijaga, added the name of a famous figure of Islamic propagator in Indonesia.

Further, some branches of IAIN spread out in other Indonesian regions with the support of Presidential Regulation No. 27/1963. The impact of the support is that there have been fourteen IAIN develop well in most area of Indonesia. Each of IAIN develops its branch to other city up to the rural areas in order to provide higher education to the broader community and to increase their human resources. The rapid growth of the institutions initiated the Minister of Religion Affairs to rationalize the organization to be an independent institution.

By 1997 and under the Presidential Decree Number 11/1997, more than 40 branches faculty of IAIN were reformed into 36 state college for Islamic Studies (STAIN) and some IAIN reformed to be Islamic university, thus becoming the state Islamic universities with the requirements. One of the requirements is IAIN that wants to transform to be UIN should have faculty of science in a sense that the institution could integrate religion with diverse fields such as social sciences, humanity, natural sciences and another fields.

Since that, IAIN Syarif Hidayatullah Jakarta was the first to be transformed into Universitas Islam Negeri/State Islamic University Syarif Hidayatullah Jakarta followed by other IAIN as showing in the following table.

Table 1. Islamic higher educational institution in Indonesia

\begin{tabular}{lll}
\hline No & Level & Names of Institution \\
\hline \multirow{4}{*}{ STAIN } & STAIN Al-Fatah, STAIN Batusangkar, STAIN Curup, STAIN Datokarama Palu, STAIN Gajah Putih \\
& Takengon \\
& STAIN Jember, STAIN Jurai Siwo Metro, STAIN Kediri, STAIN Kerinci, STAIN Kudus, STAIN \\
& Malikussaleh, STAIN Manado, STAIN Padang Sidempuan, STAIN Palangka Raya, STAIN Palopo, STAIN \\
& STAIN Parepare, STAIN Pekalongan, STAIN Ponorogo, STAIN Purwokerto, STAIN Sultan Qaimuddin \\
& STAIN Sultan Sulaiman, STAIN Syekh Abdurrahman Sidik, STAIN Syekh M. Djamil Djambek, STAIN \\
& Salatiga STAIN Sorong, STAIN Ternate, STAIN Tulungagung, STAIN Watampone and STAIN Zawiyah Cot \\
& Kala Langsa \\
& IAIN Ambon, IAIN Antasari, IAIN Ar-Raniry, IAIN Bengkulu, IAIN Imam Bonjol, IAIN Mataram, IAIN \\
& Raden Fatah, IAIN Raden Intan, IAIN Sumatera Utara, IAIN Sultan Amai, IAIN Sultan Maulana \\
& Hasanuddin, IAIN Sultan Thaha Saifuddin, IAIN Sunan Ampel, IAIN Surakarta, IAIN Syekh Nurjati, IAIN \\
& Walisongo, IAIN Khatulistiwa Pontianak, \\
& UIN Syarif Hidayatullah Jakarta, UIN Alauddin Makassar, UIN Maulana Malik Ibrahim Malang, UIN Sunan \\
& Gunung Djati Bandung, UIN Sunan Kalijaga Yogyakarta, UIN Sultan Syarif Kasim Pekanbaru Riau.
\end{tabular}

Source: www.diktis.go.id, on-line, September 30, 2013 


\subsection{Implication of Policy Change to Development of Islamic Education}

All these institutions aim at producing their graduates with faith and piety to the Almighty God, noble character and personality as well as intellectual and professional skill. Indonesian development puts STAIN, IAIN and UIN onto important and strategic position in line with national development objective, which is creating Indonesian people wholly with faith and piety and science mastery (Azra, 2000). STAIN, IAIN and UIN have been producing hundred thousand alumni in various fields, particularly religion. They cooperate in a variety of life sectors, particularly religious proselytizing education, and social activity. With religiosity approach and communication they possess, the alumni of IAIN/STAIN, played an important part in development and mitigate the negative impact of modernization. Apart from its success and role so far, STAIN IAIN and UIN still encounters some following challenges and problems (Suprayogo, 2005, p. 9).

The development of Islamic educational institution is based on the wider mandate which radically brings some profound implications to the next development of these institutions. First implication of the policy change is to let these institutions to cope a broader science and knowledge. Secondly is the wider mandate gives opportunity to these institutions in their attempt to integrate religion and secular sciences. Thirdly is the wider mandate lets the Islamic higher educational institution to have autonomy or greater autonomy in order those institutions are able to maximally develop itself, in either scientific as well as academic or management and financial field.

Fourthly, the policy change impacts Islamic educational institutions to undergo severe improvement and accountability in academic aspects in order its output (alumni) becomes more professional in either religion or general science, as well as expertise and skill. Fifthly, the improvement of cooperation with other college to create a positive synergy thereby encourages the acceleration of quality improvement.

\subsection{Business Paradigm in Developing Islamic Education}

The policy of developing higher education continually changes, particularly in lines with the changing paradigm. The leaders of Islamic educational institution formulate new paradigm in leading educational which synergizing the intellectual development, professionalism in accordance with the need of economy market without losing traditional values of Islam.

The integration is needed not only to meet the original aims of Islamic education but also in order the alumni are accountable with their surrounding and able to sell themselves in the competitive market. The policy that they took is changing the way of knowing with the new episteme of education which explicitly contains in the curriculum and learning-teaching process that based on the market orientation. Imam Suprayogo, the rector of universitas Islam Negeri Malang explicitly asserts that educational institution is a living entity that exits to meet the need of stakeholder. The paradigm change is must in order Islamic educational institution in general are not exclusive, but inclusive, open for all the possibility of current and future change.

Marketization and professionalism stressed by Imam Suprayogo are two among of fourth concepts which are required by education institution in keeping its survival as the service provider for the public. The two concepts are also to direct the relevance of knowledge and skill of the educational institution outcome to the real society development sector (Zanten, 2002, p. 293). Such the thinking justifies that the management of educational institution is as well as that of business in general as Imam Suprayogo (2006) states:

Managing higher education is as managing business institution. It should adjust its outcomes to the consumer's demand. Thus, management of this institution (UIN Malang) is always following its consumer demand which has the characters prioritizing professionalism, flexible, (3) collectively decision making, maturely developed and measurable planning, information distributed widely, competition attempted develops widely and healthily, proactive and brave to deal with risk, holding strongly on the vision and mission (Suprayogo, 2004, p. 140).

The perspective above has wide impact to view and weigh higher education as business institution generally, but also provides an up to date management perspective which closely relevant to the development and demand of education institution's role and contribution to the community development. The perspective also gives a high spirit for education institution to move forward following local, national, and global development rhythm, from national welfare age toward global welfare and must work efficiently and effectively. One characteristic of modern work is that working should be based on the planning developed objectively, rationally, full of consideration and required by clear vision and mission (Suprayogo, 2004)".

Market orientation is a central element of a management philosophy. Generally speaking, market-orientated organizations are well informed about the market to create a superior value for their outcomes. The leader of Islamic higher education is aware of the importance of market orientation for signaling the existence of the 
institution. It is a value-based strategic philosophy exhibiting itself in behaviors which help alumni of educational institutions staying close to the community and play their strategic role in developing the community and nation (Baker \& Sinkula, 2005).

More specifically, the role used leads to a significant of Islamic educational institution in assessing the community development process. The study notes some strategic role that has been widely played by the alumni in the community and nation development which are educating the nation intellectuals with noble-character, think-tank of Islam community and the society surrounding, agent of development, and creating the future figure and leader of nation, and become the role model of Islamic behavior (Djamal, 2000, p. 88).

\section{Educating the Nation Intellectuals with Noble-Character}

The complexity problem of modern business organization is seen as the impact of lacking awareness on the importance of ethics and moral values in its operational such as misuse of power for personal gain (Duerden, 1995; Desai \& Rittenberg, 1997). This is one of the reasons why ethics and moral values become important themes being addressed to the development of global business organization issues. Today's world had literally slaved the mankind for money and fame.

Teaching ethics and moral values in the modern life is a key factor that helps to build a dynamic society. The existence of Islamic educational institution in particular and educational institution in general is becoming most relevant to modern people's need. Mahoney (1990) suggests that any separate course in ethics is not enough, but materials on ethics should be included in every course in the curriculum. (Pizzolatto \& Bevill, 1996; Shannon \& Bed, 1997).

Islamic educational institution becomes a rich source of fulfilling the ethics and moral values needed by today's global community which is fading in the global organization and corporations caused which is characterized by ethical problems such as corruption erodes business and society at many levels.

(http://www.globalethics.org/newsline/members/issue.tmpl?articleid=102606184).

Minimalizing the deviant behavior from the ethics and moral values is the pivotal role of the educational institution. It is a place of institutionalizing and internalizing ethics and moral values into the mode of generation conduct in order to create the erudite and noble character of the society. (Pizzolatto \& Bevill, 1996; Shannon \& Bed, 1997).

Character in Islamic education is a keyword playing significant role for creating the noble conduct of the society. Noble character becomes principal foundation for students as the young generation who will occupy with any expertise in large sectors such as medical, sociology, law, economic, and other fields (Halim, 2007; Burren, 1999; Mahoney, 1990; Pizalota, 1999). It is realized that an individual's expertise without control and guide by moral values will lead them to disaster. There is a wide recognition that a community's standing is highly determined by the moral foundation.

\section{Think-Tank of Islam Community and the Society Surrounding}

The role as think-tank for Islam community and society surrounding imply the universal value and mission that should be assumed by the alumni of Islamic high education institution. The alumni of Islam higher educational institution have well understanding and mastery of Islamic sciences supported by other field of science inclusive of social and humanity sciences. The alumni of Islam higher education is required to be able to play think tank role, as the galley of thinkers who convey idea, concept and thought for developing and improving the society life and development in local areas generally (Djamal, 2006).

The role as think tank of community played by the alumni of Islamic higher education indicates their pivotal contribution in the community and nation development. They become a role model or leading figure in religion aspect but also in a widely public policies issue in Indonesia (Bull, 2001). An empirical fact portrays that the scientific and religiosity ability of the alumni have supported them greatly to play their role as expert. In scientific category of role they become as the agent of modernization that they perform through education, law, Islamic illumination, Islamic thought; motivator of community. These entire roles they articulated through writing in mass media, sermons, and upgrading while as the role model they are considered by the community where they involve as the flash light that can direct the conduct of the society in accordance with religion orders (Hasibuan, 1998).

\section{Agent of Development}

The agent of development's role is not a simple task in the global community. It is more complex role that needs more requirements to the alumni of an educational institution. Realizing the complex role as the agent of 
development, Islamic higher educational institution shapes its outcomes with communication ability, knowledge and technical skill that can be the means of supporting community development in local area. With expertise and skill they have, the alumni of high education institution can play their articulator role in translating the government policy into religiosity and social activity using the method understandable and workable to the society (Ali, 2000).

Such the roles can make the alumni of Islam higher educational institution the transmitter, interpreter of community and government needs and interest. They also can act as filter of negative issues which damage community, rather a band of community who creates disorder and uproar amid the society life (Djamal, 2006; Suprayogo, 2006). Another articulation channel for the alumni of Islamic educational institution beyond its conventional path is the publishing world development that gives alumni the opportunity of removing religious education genealogy for their generation, encouraging the creation of new market without precedent to intellectual products-religious, and providing subsequent place to the emergence of IAIN-originating Islamic "professional" class in press, social, cultural, and political realms at national level (Ali, 2000).

\section{Becoming the Role Model of Islamic Behavior}

Basically, human behavior is closely related to an object's knowledge and understanding. Human's attitude and action does not occur spontaneously but based on certain powers such as knowledge and understanding. Based on knowledge and understanding on a value, an individual can determine his/her attitude and behavior despite difference from majority. An individual having knowledge and understanding will not leave him/her-self stuffed with various thing moving surrounding, instead, he will attempt to create reality (social constructing) that can support knowledge, conception and value he/she believe in.

Knowledge and understanding plays an equally important role in forming individual attitude, behavior and character (socially constructed). Julia B. Botter uses Locus Control Internal (LCI) and Locus Control External (LCE) theories to explain the human conduct which is determined and controlled by many internal factors (Lukens, 2001, p. 335). While, LCE suggests that human conduct is control by external factors.

In these two roles, the alumni of Islamic higher educational institution can make initiative by setting LCI to the front in creating a behavior model that is relied on and imitated by its community by creating Islamic personality and making the noble conduct of the people surrounding them in accordance with the ethics and moral values of Islam (Azizy, 2002).

Fachry Ali noted that the monumental development of alumni's role contributes to the predisposition of Islam community's life history which shown with the emergence of prominent Islamic thinkers who contribute to the imposition of more genuine Islamic thinking conception logic in Indonesia. Dadi Darmadi also notes that alumni of Islamic educational institution contribute considerably to the Islam intellectual development in Indonesia. They not only contributes to the development and the reform of Islam education system, particularly pesantren (Islam boarding school) and madrasah (Islam institution of learning) through the context of providing teachers, but also has affected wider and open point of view, conception and interpretation on Islam in the society life (Darmadi, 2000, p. 337).

\section{Conclusion}

The elaboration above provides us a clear picture that Islamic educational system has reformed its managerial orientation and paradigm as it is demanded by the global change of educational policy. Some of the modern educational policy concepts accommodated by Islamic educational institution are autonomy, accountability, marketization and professionalism. The implemented autonomy in the Islamic educational system brings profound impacts to the future development. Some of the Islamic institution which has low level such as branch faculty of IAIN becomes an autonomy institution such Sekolah Tinggi Agama Islam Negeri that spread in many part of Indonesia. The autonomy also brings an impact to the structure or body of knowledge developed in the Islamic institution. Each institution has the rights to develop humanity, social and medical science that closes to their condition.

The impact of the paradigm change is that the leader of Islamic educational institution up-dates their management in bringing the institution to be the leading Islamic institution. They applied the accountability values in developing the institutions based on the market economy demand without losing traditional values of Islam. Injecting business metaphor into the educational institution development brings the institution closer to the consumer demand. Consequently, Islamic educational is inappropriate to defend Islamic studies which are not based on the spirit of the community development. Thus, in the community and nation development, the alumni of Islamic higher education colored the national development in many aspects. 


\section{References}

Agle, B. R., \& Van Buren, H. J. (1999). God and mammon: The modem relationship. Business Ethics Quarterly, 9(4). http://dx.doi.org/10.2307/3857935

Ahmed, E. (Ed.). (2002). Economic Growth and Human Resource Development in an Islamic Perspective. Hendorn USA: The International Iinstitute of Islamic Thought.

Alavi, H. R. (2007). Al-Ghazali on Moral Education. Journal of Moral Education, 36(3). http://dx.doi.org/10.1080/03057240701552810

Ali, F. (2000). Kontinuitas dan Perubahan: Catatan Sejarah Sosial Budaya Alumni IAIN. Jakarta.

Azizy, Q. (2004). Menggagas Paradigma Baru UIN yang Berorientasi Ilmu dan Agama. Makalah disajikan dalam seminar Nasional Menggagas Universitas Islam Negeri Masa Depan (UIN Malang).

Boyle, H. (2006). Memorization and learning in Islamic schools. Comparative Education Review, 50. http://dx.doi.org/10.1086/504819

Bull, R. A. L. (2001). Two Sides of the Same Coin: Modernity and Tradition in Islamic Education in Indonesia, 32(3).

Darmadi, D. (2000). IAIN dalam Wacana Intelektual Islam Indonesia. Jakarta: Direktorat Pembinaan Perguruan Tinggi Islam dan Dirjen Kelembagaan Agama Islam.

Daun, H., \& Walford, G. (Eds.). (2004). Educational strategies among Muslims in the context of globalization: Some national case studies. Leiden, Holland: Brill.

Dunn, W. N. (2003). Pengantar Analisis Kebijakan Publik (2nd ed.). Terj. Yogyakarta:Gajah Mada University Press.

Fadjar, H. A. M. (2006). Development Islamic education Promising Future. In M. Raharddjo (Ed.), Quo Vadis Islamic Education: Reading the Reality of Islamic Education, Social and Religion. Malang: UIN Malang Press.

Halstead, J. M. (2004). An Islamic Concept of Education. Comparative Education, 4(4). http://dx.doi.org/10.1080/0305006042000284510

Harahap, S. (Ed.). (1998). Perguruan Tinggi Islam di Era Globalisasi (Yogyakarta: Tiara Wacana).

Husain, M. G. (2004). Muslim youth and madrasa education: In Purnea district of Bihar. New Delhi, India:Institute of Objective Studies.

Jaddon, P., \& Niyozov, S. (2008). Madrasa education in South Asia and Southeast Asia: Current issues and debates. Asia Pacific Journal of Education, 28(4).

Jakobi, A. P. (2009). Global Education policy in the making: International organization and lifelong learning. Globalisation, Societies and Educaton, 7(4). http://dx.doi.org/10.1080/14767720903412275

Jonson, S. M., \& Lollar, I. L. (2002). Diversity Policy in Higher Education: The Impact of College students' exposure to diversity on cultural awareness and political participation. Journal of education Policy, 17(3). http://dx.doi.org/10.1080/02680930210127577

Lee, J. R. M. (2008). Teaching Ethics in International Business Courses: The Impacts of Religions. Journal of Teaching in International Business, 19(4). British Journal of Sociology of education, 31(5).

Leirvik, O. (2004). Religious education, communal identity and national politics in the Muslim world. British Journal of Religious Education, 26(3). Carfax Publishing. http://dx.doi.org/10.1080/0141620042000232283

Lukens-Bull, R. A. (2001). Two Sides of the Same Coin: Modernity and Tradition in Islamic Education in Indonesia. Anthropology \& Education Quarterly, 32(3). http://dx.doi.org/10.1525/aeq.2001.32.3.350

Lynch, K. (2010). Lesson for Higher Education: The University as a site of Activism. British Journal of Sociology of Education, 31(5). http://dx.doi.org/10.1080/01425692.2010.500091

Meijer, W. A. J. (2000). The Image of The Human Being In Islamic and Secular Humanistic Educational Thought A Dichotomy In The Muslim World. Religious Education, 95, 4. http://dx.doi.org/10.1080/0034408000950405

Michael, S. M., \& Driessen, G. (2005). Islamic schools in three western countries: Policy and procedure. Comparative Education, 41(4). 
Milligan, J. A. (2004). Islamization or secularization? Educational reform and the search for peace in the southern Philippines. Current Issues. Comparative Education, 7(1).

Mogra, I. (2007). Moral education in the makatib of Britain: A review of curriculum materials. Journal of Moral Education, 36(3). http://dx.doi.org/10.1080/03057240701553354

Rosenblith, S. (2004). Religious Education in A Liberal, Pluralist, Democratic State, 103(5).

Shannon, J. R., \& Bed, R. L. (1997). Are we teaching ethics in marketing? A survey of students' attitudes and perceptions. Journal of Business Ethics, 16. http://dx.doi.org/10.1023/A:1017922005651

Suprayogo, I. (2006). Memelihara Sangkar Ilmu. Malang: UIN Malang-Press.

Tamuri, Ab. H. (2007). Islamic Education teachers' perceptions of the teaching of akhlaq in Malaysian secondary schools. Journal of Moral Education, 36(3), 371-386. http://dx.doi.org/10.1080/03057240701553347

Van Zanten, A. (2002). Educational Change and New Clever ages between Head Teacher, Teachers and Parents: Global and Local Perspectives on the French Case. Journal Education Policy, 17(32).

Zanten, A. V. (2002). Educational Change and New Cleavages between Head Teachers, teachers and Parents: Global and Local Perspective on the French Case. J.E.P. Journal of Education Policy, 17(3).

Zuzevičiūtè, V. (2009). Globalizations, Mobility and Implications for Educators. TILTAI, 4(2).

\section{Copyrights}

Copyright for this article is retained by the author(s), with first publication rights granted to the journal.

This is an open-access article distributed under the terms and conditions of the Creative Commons Attribution license (http://creativecommons.org/licenses/by/3.0/). 